\title{
Translocation of arsenic in food chain: A case study from villages in Gangetic basin, India
}

\author{
D. Ghosh ${ }^{1} \&$ J. Routh ${ }^{2}$ \\ ${ }^{1}$ Centre for Earth Sciences, Indian Institute of Science, Bangalore, India \\ ${ }^{2}$ Department of Thematic Studies - Environmental Change, Linköping University, Linköping, Sweden
}

\begin{abstract}
Arsenic (As) contamination of groundwater is a worldwide concern and West Bengal in India is affected by this problem. Different food crops may accumulate As differently, and studies often show conflicting results. A previous study from Karimpur block, Nadia district, West Bengal indicated high concentration of As in two tube wells. Groundwater from these wells is used for irrigating nearby agricultural fields. The aim of this study was therefore to analyze As and other metals concentration in different vegetables and rice growing in these fields. In addition, animal fodder plants and cow milk was also analyzed to investigate the possibility of transfer of arsenic through food chain. The samples were analyzed using a microwave digestion procedure followed by inductively coupled plasma mass spectrometry. Animal fodder roots showed high concentration of As compared to other samples. The results also showed possible translocation of $\mathrm{Cd}$ along with As from root to shoot, in animal fodder. The milk samples showed high concentrations of As and $\mathrm{Pb}$.
\end{abstract}

\section{INTRODUCTION}

In many parts of the world contamination of groundwater from various inorganic and organic pollutants is a crucial problem. Over 150 million people worldwide suffer from arsenic (As) poisoning (Stroud et al., 2011). Over the past two decades extensive research efforts have been launched to investigate the role of As on humans (Bhattacharya et al., 1997). Research on the health effects has shown that changes in skin pigmentation and skin keratosis are two common consequences of exposure to high As levels in humans.

Groundwater in India is major source of drinking water. Irrigation using As contaminated aquifers could lead to translocation and biomagnification of As through various agricultural activities particularly through cereals that are consumed. There is very little information on As levels in vegetables, fruits and other food products from areas which are known As 'hot-spots' (Bhattacharya et al., 1997; Ghosh et al., 2015, 2017). Previous studies conclude there are still many uncertainties about As uptake by crops. This is due to the variations that exist between the different types of vegetation, soil types and land use practices (Kabata-Pendias \& Pendias, 1989). Moreover, toxicity and availability of As in plants depend on many factors such as: hydrology, adsorption capacity, translocation in plants etc.

The focus in various studies is on arsenic contaminated water and its effects on human, however, it is also important to investigate the link between irrigation with contaminated water and accumulation of As in food crops It is also important to trace how As is transferred through the food chain involving; water-soil food crops - humans, and impacts human health.

\section{METHODS}

\subsection{Sampling}

Sampling was done for wet (May-November) and dry (January-May) harvesting of crops in 2014, dry 2015 and wet and dry periods in 2016. The following villages of Nadia district of West Bengal, India: Haringhata, Gayeshpur, and Birohi (Chakdah Block), Rehematpur and Jamaipara (Karimpur Block), Balarampur, Sashipur, Donapur, and Kamgachia (Ranaghat Block). There were earlier reports of As contamination in the groundwater from these aquifers. Young and mature vegetable samples were collected from the field along with the soil sample and irrigation water samples from the respective fields. In addition, animal fodder (Sorghum) plants and milk samples were collected from these villages.

\subsection{Extraction and quantification}

The samples were lyophilized and powdered. About $0.5 \mathrm{~g}$ of each sample was used to extract the trace metals using microwave assisted technique with $\mathrm{H}_{2} \mathrm{O}_{2}$ and $\mathrm{HNO}_{3}$. Blanks and replicates were performed to ensure quality control of the analytical procedures. The SMR 1547 - Peach leaf from National Institute of Standards and Technology, BCR Reference Material Nr. 62 OLEA EUROPAEA Commission of the European Communities and Certified Reference Material: NIMT/UOE/FM/001 Inorganic Elements in Peat were used to correct the methodological errors if any.

Trace metal analyses in the extracts was done on a Perkin Elmer ICP-Mass Spectrometer NexION 300D. 


\section{RESULTS AND DISCUSSION}

The vegetable samples collected during the dry harvest period in all three years had higher accumulation of $\mathrm{As}$, and other heavy metals like $\mathrm{Pb}, \mathrm{Cd}$, and $\mathrm{Zn}$, in comparison to the monsoon crops. The possible reason could be the water source used for irrigation. Crops grown during the dry harvest period are irrigated using groundwater, whereas crops during the wet period are irrigated using rainwater (Shrivastava et al., 2015). However, statistical analyses did not show any co-relation between As and trace metal accumulation within the vegetables. The highest As accumulation was observed in rice (both polished and unpolished varieties) and animal fodder plants. The specific reasons are unknown. However, a possible explanation could be that phosphate transporters found in cell membrane wall of the family Poaceae, easily translocates As, which has stoichiometric similarity to it.

The sampling stations were divided into two groups, high and low As rich aquifers. Milk and vegetable samples showed a clear grouping with respect to their sampling site. However, accumulation of As also occurred in milk samples collected during both seasons from all stations.

The ability of translocation characteristics of various metals within a plant can be calculated using translocation factor (TF). Results $>1$ would indicate translocation of the selected metal (Zabin \& Howladar, 2015).

$\mathrm{TF}=\left(\mathrm{As}_{\text {shoot }}\right) /\left(\mathrm{As}_{\text {root }}\right)$

Transportation characteristics of various trace metals were calculated for animal fodder samples. The results indicated generally low TF values. Other than As $(\mathrm{TF}=1.93)$, only one trace metal showed indication of possible translocation from root to shoot i.e. $\mathrm{Cd}$ with a TF value of 1.40 . For the rest of the trace metals, the indication of translocation from root to shoot was generally less and none of the selected trace metals exceeded the TF value of 1 . Chromium and Co had the lowest TF value ( 0.01$)$ for both animal fodder samples.

In general, $\mathrm{Cu}$ has low mobility and it mostly accumulates in roots (Kabata-Pendias \& Pendias, 1989). Consistent with this, the results of $\mathrm{TF}$ values for $\mathrm{Cu}$ ( 0.25 and 0.33$)$ indicated there is no translocation of $\mathrm{Cu}$ from root to shoot. Both translocation factor and bioconcentration factors are needed to evaluate the specific potential by a plants for phytoremediation (Usman et al., 2013).

\section{CONCLUSIONS}

Overall, the study shows the translocation of As and other trace metals into higher animals through the food chain. The contaminated groundwater used for irrigation leads to accumulation of As in animal fodder, which is consumed by cattle and accumulates in milk. Human is the ultimate consumer of all these products including the different food crops and milk. This most likely leads to the different As-related health problems in the area. Drinking water is one of the major way of As entering into human body, and many measures have been taken to reduce the contamination levels in drinking water. More research is required to understand the As accumulation pathways and how can As accumulation be reduced by using GMO crops or by pre-treating irrigation water by either chemical treatment or phyto-remediation.

\section{ACKNOWLEDGEMENTS}

We thank the Swedish Research Link- Asia Program for funding the research. Indira Pasic, Molly Aylesbury, and Mårten Dario helped us with the laboratory analyses.

\section{REFERENCES}

Stroud, J.L., Norton, G.J., Islam, M.R., Dasgupta, T., White, R.P., Price, A.H., Meharg, A.A., McGrath, S.P. \& Zhao, F.J. 2011. The dynamics of arsenic in four paddy fields in the Bengal delta. Environ. Pollut. 159: 947-953.

Bhattacharya, P., Chatterjee, D. \& Jacks, G. 1997. Occurrence of arsenic contaminated groundwater in alluvial aquifers from Delta Plains, Eastern India: options for safe drinking water supply. Int. J. Water Resour. Manag. 13, 79-82.

Ghosh, D., Routh, J., Därio, M. \& Bhadury, P. 2015. Elemental and biomarker characteristics in a Pleistocene aquifer vulnerable to arsenic contamination in the Bengal Delta Plain, India. Appl. Geochem. 61:87-98.

Ghosh, D., Routh, J. \& Bhadury, P. 2017. Sub-surface biogeochemical characteristics and its effect on arsenic cycling in the Holocene grey sand aquifers of the Lower Bengal Basin. Front. Environ. Sci. 5:82.

Shrivastava, A., Ghosh, D., Dash, A. \& Bose, S. 2015. Arsenic Contamination in Soil and Sediment in India: Sources, Effects, and Remediation. Curr. Pollution Rep.: 35-46.

Kabata-Pendias, A. \& Pendias, H. 1989. Trace elements in soils and plants; CRC Press: Boca Raton, FL.

Usman, A.R.A., Alkredaa, R.S. \& Al-Wabel, M.I. 2013. Heavy metal contamination in sediments and mangroves from the coast of Red Sea: Avicennia marina as potential metal bioaccumulator. Ecotoxicol. Environ. Saf. 97: 263-270.

Zabin, S.A. \& Howladar, S.M. 2015. Accumulation of $\mathrm{Cu}$, $\mathrm{Ni}$ and $\mathrm{Pb}$ in selected native plants growing naturally in sediments of water reservoir dams, Albaha Region, KSA.Nature and Science 13(3): 11-17. 